\title{
Coxsackievirus A16-like particles elicit neutralizing antibody responses in mice
}

\author{
Qingwei Liu ${ }^{1 *}$, Kexia Yan², Yanfang Feng ${ }^{1}$, Yicun Cai ${ }^{1}$, Zhong Huang ${ }^{1}$ \\ From Institut Pasteur International Network Annual Scientific Meeting \\ Hong Kong. 22-23 November 2010
}

Coxackievirus A16 (CVA16) is one of the major causative agents of hand, foot, and mouth disease (HFMD) currently prevalent in many countries and regions in the Far East. However, no vaccine for HFMD is yet available. Here we reported the production of CVA16 viruslike particle (VLP) and its immunogenicity in mice. Coexpression of P1 and 3CD of CVA16 in a baculovirus/ insect cell system resulted in correct cleavage of P1 to yield subunit proteins VP0, VP1 and VP3. These three proteins were found to co-sediment by sucrose gradient analysis and assemble into VLPs. Mice immunized with VLPs generated high-titer CVA16-specific antibodies which efficiently neutralize live CVA16 in vitro. Collectively, our results indicate that CVA16-VLP can elicit potent neutralizing antibody responses and is therefore a promising vaccine candidate against CVA16 infection.

Coxackievirus A16 (CVA16) is one of the major causative agents of hand, foot, and mouth disease (HFMD) currently prevalent in many countries and regions in the Far East. However, no vaccine for HFMD is yet available. Here we reported the production of CVA16 viruslike particle (VLP) and its immunogenicity in mice. Coexpression of P1 and 3CD of CVA16 in a baculovirus/ insect cell system resulted in correct cleavage of P1 to yield subunit proteins VP0, VP1 and VP3. These three proteins were found to co-sediment by sucrose gradient analysis and assemble into VLPs. Mice immunized with VLPs generated high-titer CVA16-specific antibodies which efficiently neutralize live CVA16 in vitro. Collectively, our results indicate that CVA16-VLP can elicit potent neutralizing antibody responses and is therefore a promising vaccine candidate against CVA16 infection.

\footnotetext{
* Correspondence: qwliu@sibs.ac.cn

${ }^{1}$ Key laboratory of Molecular Virology \& Immunology, Institute Pasteur of Shanghai, Chinese Academy of Sciences, Shanghai 200025, PR China Full list of author information is available at the end of the article
}

\section{Author details}

${ }^{1}$ Key laboratory of Molecular Virology \& Immunology, Institute Pasteur of Shanghai, Chinese Academy of Sciences, Shanghai 200025, PR China.

${ }^{2}$ Biodesign Institute, Arizona State University, Tempe, Arizona 85287, USA.

Published: 10 January 2011

doi:10.1186/1753-6561-5-S1-P28

Cite this article as: Liu et al:: Coxsackievirus A16-like particles elicit neutralizing antibody responses in mice. BMC Proceedings 2011 5(Suppl 1):P28.
Submit your next manuscript to BioMed Central and take full advantage of:

- Convenient online submission

- Thorough peer review

- No space constraints or color figure charges

- Immediate publication on acceptance

- Inclusion in PubMed, CAS, Scopus and Google Scholar

- Research which is freely available for redistribution
() Biomed Central 